\section{The Tax Man Cometh: Consumer Spending and Tax Payments}

\section{Peter S. Yoo}

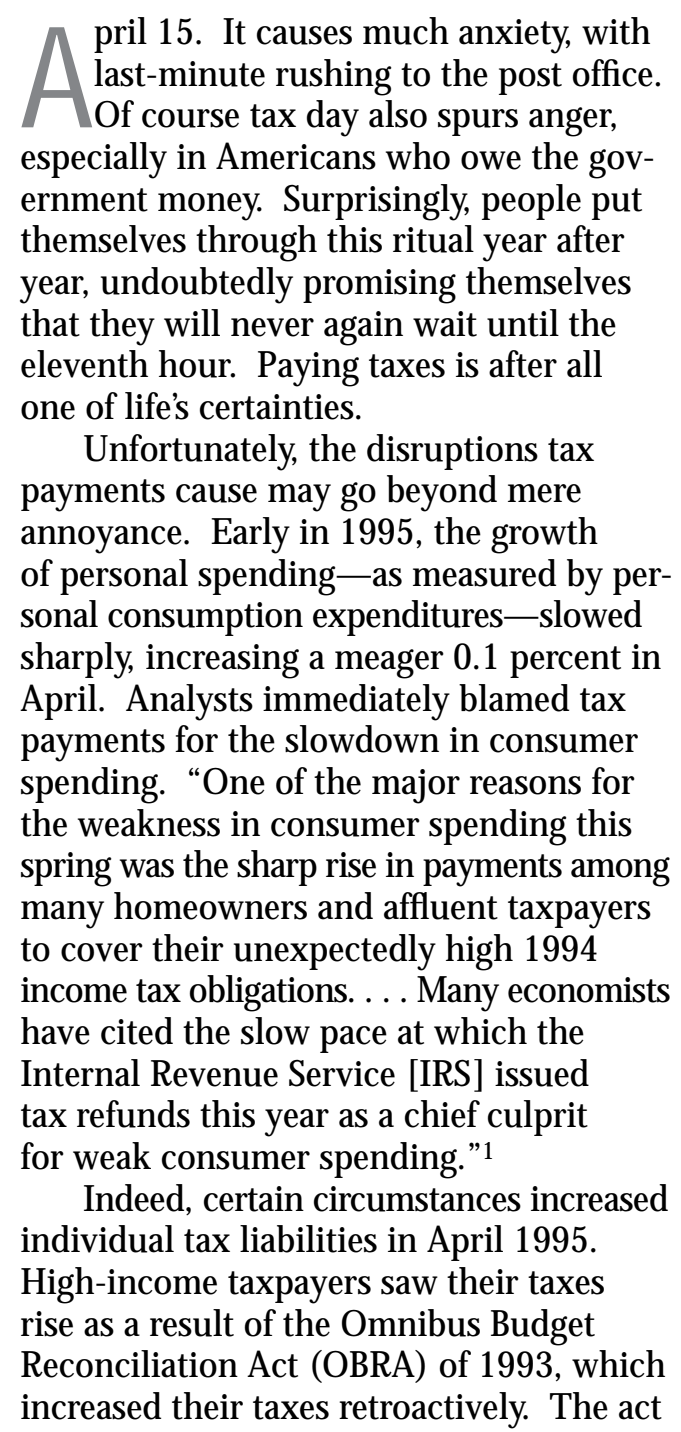

gave them the option of distributing their increased tax bill over three years. The second installment was due in April 1995. In addition, the IRS was more careful in its review of tax returns, delaying some tax refunds. ${ }^{2}$ Both of these factors increased individual tax payments in April, even though the increase attributable to refund delays was temporary. The story for the analysts, therefore, was simple: Tax payments went up, disposable income fell, and so consumer spending fell.

Is the story so simple? Does consumer spending change when tax payments change? To answer this, I present several episodes in which tax payments changed noticeably.

\section{TAXES AND \\ CONSUMER SPENDING}

Traditional economic models present consumer spending as a function of disposable personal income. So any change in tax payments directly affects disposable personal income, thereby changing consumer spending. Typically, these models do not include expectations about future income. Because changes in tax payments reduce current disposable personal income dollar for dollar, the models predict that such changes contemporaneously have a large effect on consumer spending.

Recent models of consumer behavior, however, are more ambiguous about the contemporaneous link between tax payments and consumer spending. These models argue that people consider their lifetime resources when making spending decisions. If this indeed is the case, individuals should adjust their savings, thereby spreading the impact of tax liability changes over a longer period. In essence, these models assert that people have other and possibly better alternatives to merely changing their spending dollar for dollar because they can adjust their mix of consumption expenditures and savings.

\footnotetext{
${ }^{1}$ See J ohnston (1995).

2 Berry (1995) and Hershey (1995) reported that some economists attributed the slowdown in February's retail sales to the slow refunds.
} 


\section{Table 1}

\section{Changes in Individual Tax Liabilities}

\begin{tabular}{|c|c|c|c|}
\hline Act/ Event & Month Enacted & Effective Date & Description \\
\hline Revenue Act of 1964 & February 1964 & March 1964 & $\$ 11$ billion tax cut \\
\hline $\begin{array}{l}\text { Revenue and Expenditure } \\
\text { Control Act of } 1968\end{array}$ & June 1968 & April 1968 & 10 percent surcharge \\
\hline Tax Reform Act of 1969 & December 1969 & J anuary 1970 & Extended surcharge \\
\hline Revenue Adt of 1978 & November 1978 & January 1979 & $\$ 19$ billion tax cut \\
\hline $\begin{array}{l}\text { Economic Recovery } \\
\text { Act of } 1981\end{array}$ & August 1981 & October 1981 & 25 percent cut in tax rates \\
\hline Tax Reform Act of 1986 & October 1986 & J anuary 1987 & Major tax code overhaul \\
\hline OBRA 1990 & October 1990 & J anuary 1991 & Tax increase on high income \\
\hline OBRA 1993 & August 1993 & J anuary 1993 & Tax increase on high income \\
\hline Tax Rebate 1975 & March 1975 & May 1975 & Up to $\$ 200$ tax rebate \\
\hline Refund Delays* & & & \\
\hline
\end{tabular}

Another reason to be wary of analyses that attribute changes in consumer spending to changes in tax payments is that changes in personal income, also induce dollar-fordollar changes in disposable personal income. (The two measures of income are related by the following national income accounting identity: disposable personal income $=$ personal income - personal tax and nontax payments.) So there may be periods when changes in consumer spending are in response to changes in personal income and not to changes in tax payments. That is what most likely happened early in 1995. As the growth of personal consumption expenditures fell, personal income growth also fell. Personal income grew 0.5 percent in March 1995 but rose only 0.2 percent in April 1995. It is likely, therefore, that the slowdown in personal income growth accounted for the slowdown in consumer spending.

Any examination of the relationship between changes in tax liabilities and changes in consumer spending, therefore, should consider a wide time frame, changes in personal income, and the possibility that individuals diffuse the impact of such changes by altering their savings. First, in my analysis, I use a 12-month window surrounding the changes in tax payments. This provides a time frame in which to observe the response of consumer spending beyond the period when a change in tax payment occurred.

Second, the analysis asks how much individuals spent out of every dollar of personal income and disposable personal income. Economists call this measure of spending the average propensity to consume- merely a ratio of consumer spending to a measure of personal income:

$$
\begin{gathered}
A P C \text { out of } P I=\frac{P C E}{P I} \\
A P C \text { out of } D P I=\frac{P C E}{D P I(=P I-T)},
\end{gathered}
$$

where APC is average propensity to consume, $\mathrm{PI}$ is personal income, DPI is disposable personal income, PCE is personal consumption expenditures, and $T$ is tax and nontax payments. 


\section{REVIEW}

J ANUARY/ FEBRUARY 1996

\section{Figure 1}

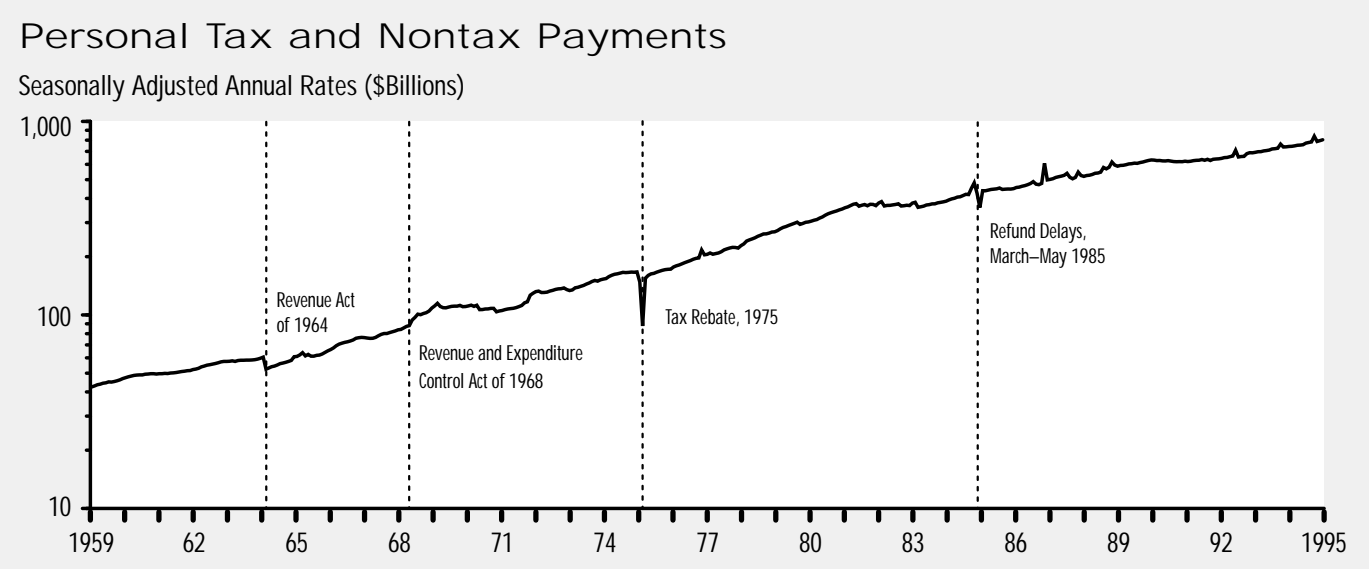

Typically, these two measures of APC move in tandem, but there are occasions when the relative movements diverge. The divergences occur because any change in tax payments affects disposable personal income dollar-for-dollar but has no effect on personal income. Since changes in tax liabilities do not affect personal income, APC out of personal income will reflect the response of consumer spending to changes in tax payments. Changes in tax liabilities do affect disposable personal income, however. So, if consumer spending does not react to a change in tax payments, APC out of disposable income will move in the opposite direction of the change in tax liabilities. If consumer spending is not responsive to changes in tax liabilities, the two ratios will thus behave differently.

Finally, in my analysis I track the behavior of personal saving because individuals may use their savings as a buffer against changes in tax liabilities, increasing the amount saved if tax payments fall and reducing the amount saved or borrowed if tax payments increase. I therefore examine the behavior of personal saving rates, ratios of personal saving to personal and disposable personal incomes.

\section{IDENTIFYING CHANGES IN TAX LIABILITIES}

To examine the relationship between taxes and consumer spending, I first had to identify periods in which tax payments increased or decreased. The personal income tax rate changed at least eight times from 1959 through 1995 because of the Revenue Act of 1964, Revenue and Expenditure Control Act of 1968, Tax Reform Act of 1969, Revenue Act of 1978, Economic Recovery Act of 1981, Tax Reform Act of 1986, OBRA 1990, and OBRA 1993. ${ }^{3}$ Table 1 provides a brief summary of these tax law changes. Pechman (1987), Hakkio et al. (1993) and Congress and the $N$ ation provide more comprehensive summaries about the changes in the tax code.

The Department of Commerce publishes seasonally adjusted, monthly estimates of personal tax and nontax payments. ${ }^{4}$ These estimates include federal, state, and local taxes, as well as nontax payments. Figure 1 shows the path of monthly personal tax and nontax payments since 1959, and it indicates that some of the changes in federal tax laws had identifiable effects on this series. Figure 1 also shows few prominent spikes that do not correspond to one of the noted changes in tax law. Personal tax and nontax payments show a sharp drop in 1975. This is attributable to a tax rebate offered in May 1975. The series also behaved oddly in early 1985 because there was a delay in tax refunds. Table 1 briefly describes these two special cases as well.

As you can see in Figure 1, not all tax law changes noted in Table 1 show changes in personal tax payments. This is probably
${ }^{3}$ I examined this period because personal consumption expenditure data are available back to January 1959.

${ }^{4}$ Nontax payments include passport fees, fines and penalties, donations, and tuitions and fees paid to government-operated schools and hospitals. See Byrnes et al. (1979) for a discussion of the construction of the personal income statistics. 


\section{Figure 2}

\section{Revenue Act of 1964}

Income and Consumption

Seasonally Adjusted Annual Rates (\$Billions)

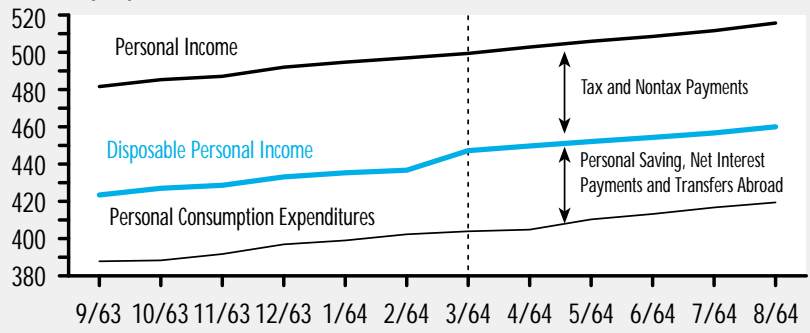

\section{Average Propensitites to Consume}
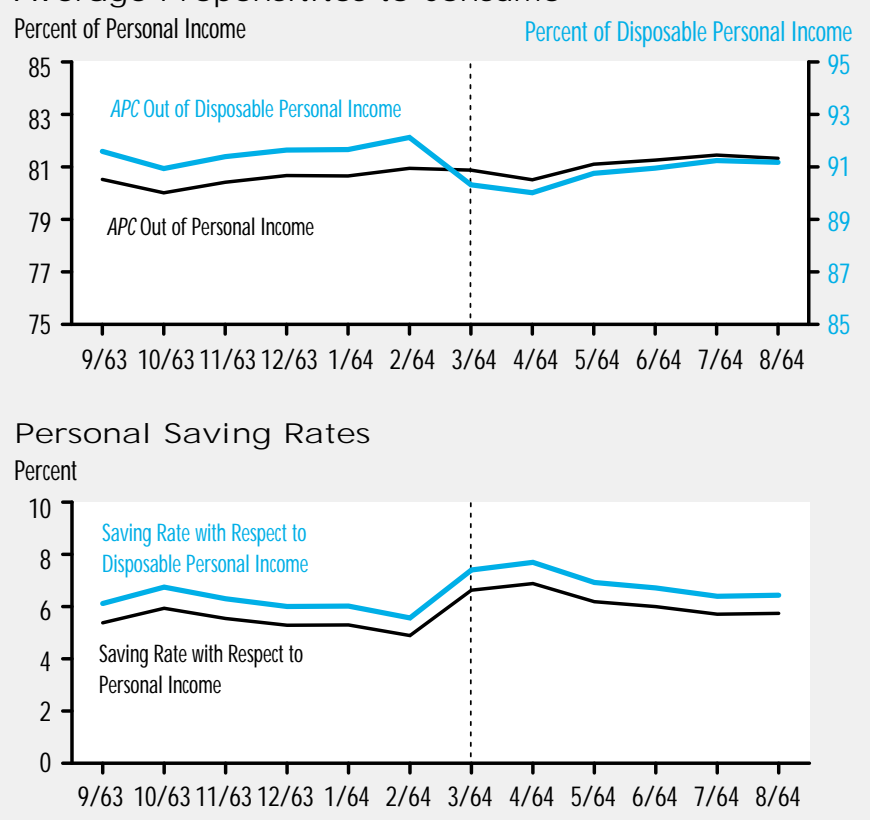

because of changes in economic conditions or because individuals altered their behavior to circumvent the changes in the tax code. This presents a problem with the simple analysis I have proposed. Therefore, I focus on one tax cut (the Revenue Act of 1964) and one tax increase (the Revenue and Expenditure Control Act of 1968). I also examine two other episodes- the tax rebate of 1975 and the refund delays of 1985. Unlike the first two episodes, these two were unexpected or nearly unexpected. An episode's forecastability is important because modern consumption theory states that individuals adjust their behavior to minimize the disruptive nature of predictable future events. It is possible, therefore, that consumer spending did not respond contemporaneously to changes in taxes because consumers had adjusted their behavior well in advance of the changes taking effect. All four episodes show observable changes in personal tax and nontax payments.

\section{WHAT HAPPENED TO CONSUMPTION?}

\section{Revenue Act of 1964}

Congress passed the Revenue Act of 1964 in February of that year, and the changes took effect that $M$ arch. The act substantially reduced individual taxes, decreasing personal tax and nontax payments by $\$ 8.1$ billion between February and March.

So how did consumers react to this tax cut? Consumer expenditures, as illustrated in Figure 2, suggest consumers did not react during the 12 months surrounding the tax cut. Table 2 summarizes the behavior of tax and nontax payments, personal consumption expenditures, and personal saving near the effective dates of the four episodes.

The path of consumer spending shows little discernable movement between February and March of 1964. The change in personal consumption expenditures between the two months was merely $\$ 1.6$ billion. It is possible, however, that other factors (like changes in personal income) may be distorting the picture. The top panel of Figure 2 al so shows that personal income growth was relatively constant during the sample period. In contrast, disposable personal income rose noticeably when the tax cut took effect.

Disposable income rose, and consumer spending did not change. What happened to the extra money? Most likely, people saved it. Personal saving rose by $\$ 8.8$ billion between February and $M$ arch, very close to the reduction in tax payments between the same two months. The difference between disposable personal income and personal consumption expenditures 


\section{Table 2}

\begin{tabular}{|c|c|c|c|}
\hline & $\begin{array}{l}\text { Tax and Nontax } \\
\text { Payments }\end{array}$ & $\begin{array}{l}\text { Personal Consumption } \\
\text { Expenditures }\end{array}$ & $\begin{array}{c}\text { Personal } \\
\text { Saving }\end{array}$ \\
\hline $\begin{array}{l}\text { Revenue Act of } 1964 \\
\text { (February-March) }\end{array}$ & -8.1 & 1.6 & 8.8 \\
\hline $\begin{array}{l}\text { Revenue and Expenditur } \\
\text { Control Act of } 1968 \\
\text { (June-July) }\end{array}$ & 6.0 & 6.8 & -7.1 \\
\hline $\begin{array}{l}\text { Tax Rebate of } 1975 \\
\text { (April-May) }\end{array}$ & -60.1 & 24.2 & 49.0 \\
\hline $\begin{array}{l}\text { Refund Delays of } 1985 \\
\text { (February-March) } \\
\text { (April-May) }\end{array}$ & $\begin{array}{r}30.1 \\
-66.6\end{array}$ & $\begin{array}{r}6.2 \\
35.2\end{array}$ & $\begin{array}{r}-16.2 \\
21.3\end{array}$ \\
\hline
\end{tabular}

(personal saving, net interest payments, and transfers abroad) rose sharply once the tax cut took effect, corresponding to the increase in personal saving. ${ }^{5}$ The sharp increase in personal saving of nearly the same magnitude as the drop in personal tax and nontax payments suggests that the tax cut that took place in 1964 did not affect consumer spending near the time the cut took place, but rather led individuals to save more.

Figure 2 provides another way to see what happened to consumer spending's response to the change in tax liabilities. The middle panel shows the two measures of APC out of income. APC out of personal income shows little change during the 12 months, but APC out of disposable personal income shows a noticeable drop between February and March of 1964. The divergence of the two ratios is consistent with the hypothesis that the tax cut did not coincide with a change in consumer spending in the short run. APC out of personal income did not change because neither personal consumption expenditures nor personal income changed, whereas APC out of disposable personal income decreased because disposable personal income increased when tax payments fell. People responded by increasing their saving rates as indicated by the rise in the two personal saving rates between the two months in the third panel of Figure 2.

\section{Revenue and Expenditure Control Act of 1968}

The Revenue and Expenditure Control Act of 1968 provides an opportunity to see the response of consumer spending to increased tax payments. The act, established in June 1968, called for a 10 percent income-tax surcharge, retroactive to A pril 1968. The effect on personal tax and nontax payments began in July of the same year. Personal tax and nontax payments increased by $\$ 6$ billion between June and July 1968.

How did individuals respond to the increase in tax payments? Personal consumption expenditures increased $\$ 6.8$ billion between June and July, not at all consistent with the traditional theory that higher taxes reduce consumer spending. Moreover, the relative stability of personal income and personal consumption expenditures occurring at a time of increased tax payments produce the divergence of the two measures of APC, as shown in Figure 3 (p.42). APC out of personal income shows little change during the 12 months, but APC out of disposable personal income shows a noticeable increase between June and July because disposable personal income fell as a result of the tax increase. This is consistent with the hypothesis that the tax increase did not affect personal consumption expenditures. How then did they pay

\footnotetext{
${ }^{5}$ Although personal saving is only a part of this sum, it is the largest of the three components. Furthermore, net interest payments and transfers abroad did not change much during the period.
} 


\section{Figure 3}

\section{Revenue Act of 1968}

Income and Consumption

Seasonally Adjusted Annual Rates (\$Billions)

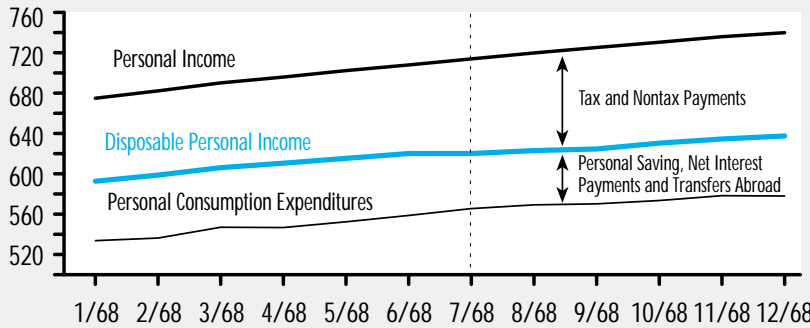

Average Propensitites to Consume

Percent of Personal Income Percent of Disposable Personal Income

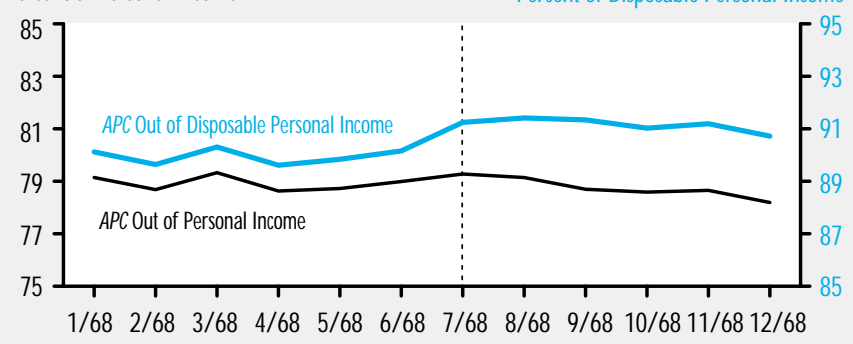

\section{Personal Saving Rates}

Percent

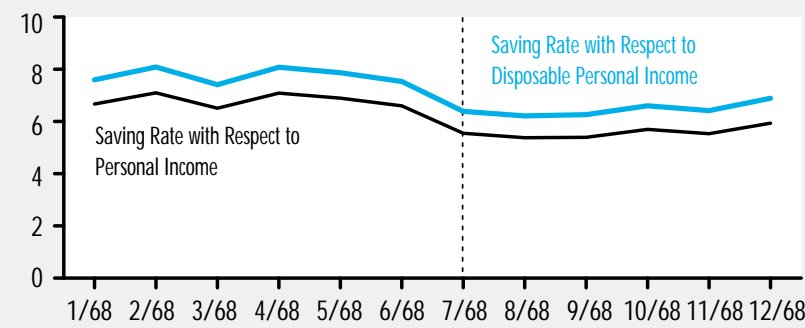

${ }^{6}$ Shapiro and Slemrod (1995) used survey data to analyze the impact of the 1992 reduction in withholding. They found that the temporary tax cut affected consumer spending among some individuals, increasing consumer spending 43 cents for every dollar reduction in withholding. Their number shows what happened to an average dollar of additional income. A crude, comparable number is a ratio of the change in personal consumption expenditures to the change in tax payments. That ratio is 40.3 cents. for the additional taxes? Personal saving fell by $\$ 7.1$ billion between the two months, an amount more than enough to pay for the higher tax payments. This drop in saving accounts for the fall in the two measures of personal saving rates shown in the bottom panel of Figure 3.

\section{Tax Rebate of 1975}

As a result of the tax rebate bill enacted in March 1975, the IRS issued rebate checks. This reduced personal tax and nontax payments by $\$ 60.1$ billion between April and May 1975. Consumers reacted by increasing personal consumption expenditures by $\$ 24.2$ billion-a large amount, but less than half the reduction in tax payments. ${ }^{6}$ Therefore, the upward tick in APC out of personal income reflects an increase in consumption. The sharp drop in APC out of disposable income and the increase in APC out of personal income is consistent with the hypothesis that people spent some of, but not all, the extra money they received from the rebate. The rebate increased disposable personal income but did not affect personal income, as shown in Figure 4.

What was not spent was saved. Personal saving increased $\$ 49$ billion, which more than accounts for the difference between the drop in tax payments and the increase in spending. The higher saving increased personal saving rates with respect to personal and disposable personal incomes. So unlike the revenue acts discussed earlier, the data indicate that there was some contemporaneous movement of consumer spending to a change in tax liabilities; however, individuals absorbed most of the impact of the tax change by modifying their saving.

\section{Refund Delay of 1985}

In 1985 the IRS fell behind in issuing refunds because it was updating its computers. This caused an initial rise in tax payments in March. By May, however, refunds were back on track, depressing tax payments. The initial delay coincided with an increase in personal tax and nontax payments of $\$ 30.1$ billion between February and $M$ arch. Once the IRS resolved its problems, tax payments dropped $\$ 66.6$ billion between April and May.

So what did consumers do when their promised checks were late? Personal consumption expenditures increased $\$ 6.2$ billion during the delay; a $\$ 35.2$ billion increase in consumer spending coincided with the reversal. The initial increase is once again contrary to the reaction typically attributed to increases in tax payments. The latter increase accounts for nearly half of the reversal in refund delays. A delay in refunds first increases net tax payments, reducing disposable income, as shown in Figure 5 
(p.44). So if consumer spending does not change, the ratio of consumption to personal income does not move because movements in tax payments do not affect personal income. In contrast, the ratio of consumption to disposable income rises as disposable income falls. Once refunds arrive, consumers have more disposable income, but if they have not altered their spending, their APC out of disposable personal income falls while their APC out of personal income remains constant.

Figure 5 indicates that people reacted somewhat to the timing of refunds because APC out of personal income shows a small decrease in $M$ arch and a large increase in May. This is consistent with an initial drop followed by a rise in consumer spending in response to the timing of the refunds. The behavior of APC out of disposable personal income is also consistent with consumers' slight reaction to the timing of refunds. APC out of disposable income rose between February and M arch 1985 and then fell between April and May.

Again, data are consistent with the hypothesis that individuals used their savings to absorb most of the changes in tax payments. As net tax payments increased between February and M arch, personal saving fell $\$ 16.2$ billion, then as net tax payments decreased between A pril and May, personal saving rose $\$ 21.3$ billion. Although these figures are not as large as the changes in personal tax and nontax payments, they account for a sizable portion of the changes in taxes. Figure 5 indicates that personal saving rates with respect to personal and disposable personal incomes decreased then increased as net tax payments rose and fell. ${ }^{7}$ It appears that individuals thus offset the negative impact of refund delays with reduced spending and saving. They then reversed their actions once they received their refunds.

\section{CONSUMERS REACT- SOM EW HAT}

My analysis suggests that consumers react only somewhat to changes in tax lia-

\section{Figure 4}

\section{Tax Rebate of 1975}

Income and Consumption

Seasonally Adjusted Annual Rates (\$Billions)
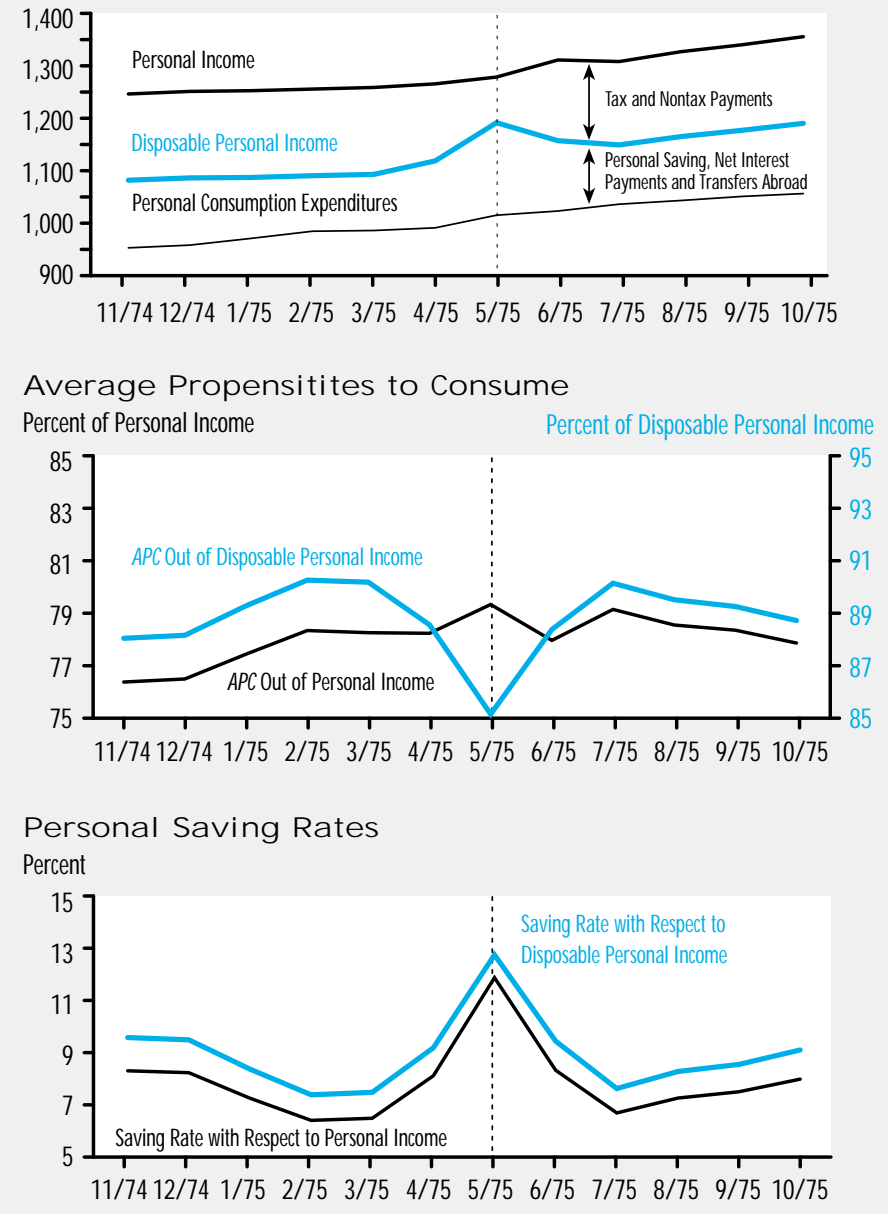

bilities. The tax cut of 1964 and the tax hike of 1968 produced very little response in consumer spending. Moreover, accounting for individuals' ability to adjust to predictable events does not significantly change the conclusion about consumer sensitivity. The four cases suggest that consumers are reluctant to change their spending patterns and thus al ter their savings to compensate for changes in their tax payments. If any sensitivity exists, it appears to be more in response to unexpected, rather than expected, events- even then the reaction is not large.

\footnotetext{
${ }^{7}$ Wilcox (1990) studied the effects of the timing of tax refunds on consumer spending, including the 1985 delay. He found that a dollar of received tax refunds translates into 7.5 cents of additional spending.
} 


\section{Figure 5}

\section{Refund Delays of 1985 \\ Income and Consumption \\ Seasonally Adjusted Annual Rates (\$Billions) \\ 3,500

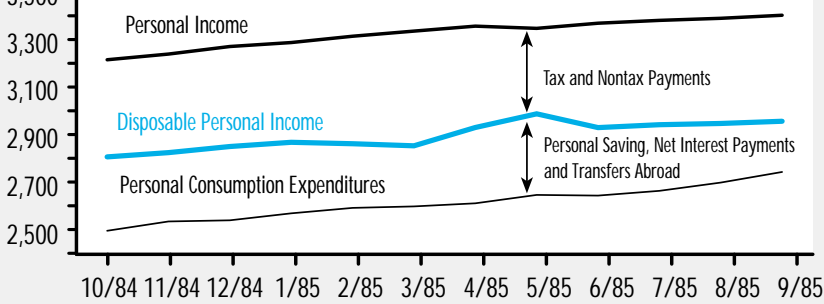

\section{Average Propensitites to Consume}

Percent of Personal Income

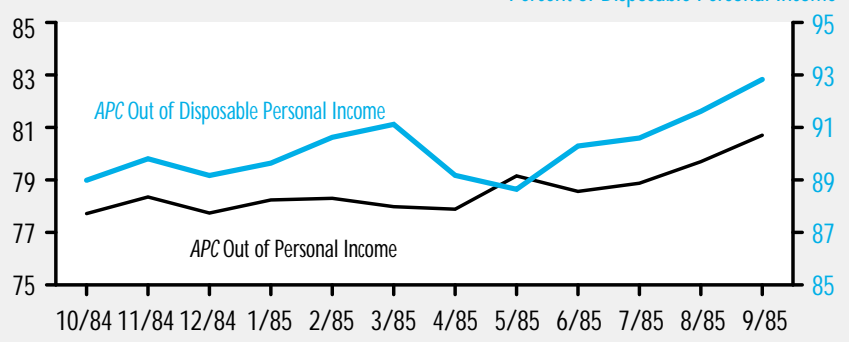

Personal Saving Rates

Percent

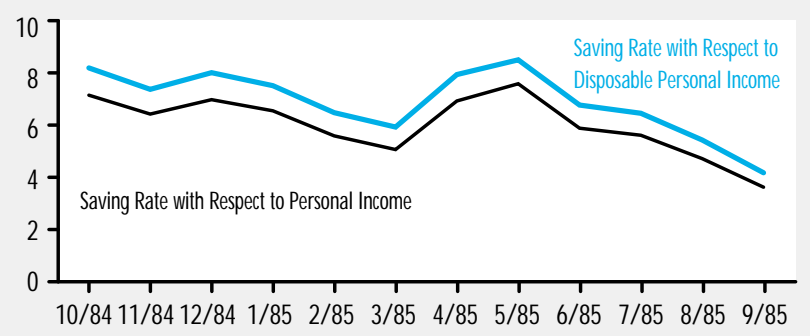

\section{REFERENCES}

Berry, John M. "Retail Sales Fell 0.5\% in February," Washington Post, March 15, 1995.

Byrnes, James C., et al. "Monthly Estimates of Personal Income, Taxes, and Outlays," Survey of Current Business (November 1979), pp. 18-37.

Congressional Quarterly Service, Inc. Congress and the Nation (various issues).

Hakkio, Craig S., Mark Rush, and Timothy J. Schmidt. "The Marginal Income Tax Rate Schedule from 1930 to 1990," Federal Resenve Bank of Kansas City Research Working Paper 93-12 (October 1993).

Hershey, Robert D., Jr. "February Retail Sales Had Surprising Slide," New York Times, March 15, 1995.

Johnston, David Cay. "Weak Consumer Spending is Linked to Tax Bite," New York Times, June 2, 1995.

Pechman, Joseph A. Federal Tax Policy. The Brookings Institution, 1987.

Shapiro, Matthew D., and Joel Slemrod. "Consumer Response to the Timing of Income: Evidence from a Change in Tax Withholding," American Economic Review (March 1995), pp. 274-83.

Wilcox, David W. "Income Tax Refunds and the Timing of Consumption Expenditure," Board of Governors of the Federal Reserve System Working Paper Series No. 106 (April 1990). 